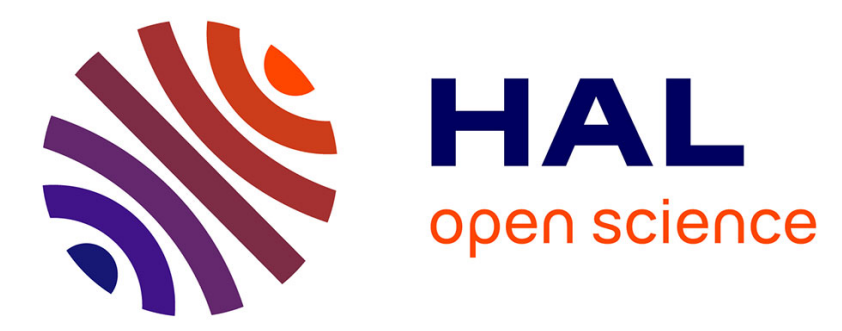

\title{
Rhetoric and logic in Smith's Description of the Division of Labor \\ Jean-Louis Peaucelle
}

\section{To cite this version:}

Jean-Louis Peaucelle. Rhetoric and logic in Smith's Description of the Division of Labor. European Journal of the History of Economic Thought, 2012, 19 (3), pp.385-408. 10.1080/09672567.2010.499473 . hal-01402198

\section{HAL Id: hal-01402198 \\ https://hal.univ-reunion.fr/hal-01402198}

Submitted on 24 Nov 2016

HAL is a multi-disciplinary open access archive for the deposit and dissemination of scientific research documents, whether they are published or not. The documents may come from teaching and research institutions in France or abroad, or from public or private research centers.
L'archive ouverte pluridisciplinaire HAL, est destinée au dépôt et à la diffusion de documents scientifiques de niveau recherche, publiés ou non, émanant des établissements d'enseignement et de recherche français ou étrangers, des laboratoires publics ou privés. 


\title{
Rhetoric and Logic in Smith's Description of the Division of Labor
}

Author: Jean-Louis Peaucelle

jean-louis.peaucelle@univ-reunion.fr

JL Peaucelle was born in 1943. Before retiring, he worked as a Professor at the University of Reunion Island, where he taught organisation theories. He also taught Information Systems at the University of Paris I. He is the author of a book in French about traditional processes of pinmaking.

Keywords: Adam Smith, division of labor, rhetoric, logic, technology.

\begin{abstract}
:
This article analyses the first chapter of the Wealth of Nations, where the division of labor is defined and its effects described. It first shows the rhetoric and logical effects which are used to win the reader's goodwill. Then it reviews $19^{\text {th }}$ century debates on the validity of the theory. Lastly it cites three real cases where the division of labor does not increase the productive power of labor. In conclusion, it suggests that the theory on division of labor appears to require some adjustment, while acknowledging that some of the facts underlying arguments in its support are naturally true.
\end{abstract}




\title{
Rhetoric and Logic in Smith's Description of the Division of Labor
}

Keywords: Adam Smith, division of labor, rhetoric, logic, technology.

\begin{abstract}
:
This article analyses the first chapter of the Wealth of Nations, where the division of labor is defined and its effects on productivity described. It first shows the rhetoric and logical effects which are used to win the reader's goodwill. Then it reviews $19^{\text {th }}$ century debates on the validity of the theory. Lastly it cites three real cases where the division of labor does not increase the productive power of labor. In conclusion, it suggests that the theory on division of labor appears to require some adjustment, while acknowledging that some of the facts underlying arguments in its support are naturally true.
\end{abstract}

"The division of labour so far as it can be introduced, occasions, in every art, a proportionable increase of the productive powers of labour." (Smith, 1776, Book 1, Chapter 1981 p. 15 VolVol. 1).

Almost everyone is familiar with this idea of Adam Smith's, upon which he bases his conception of means to increase the Wealth of Nations. Some authors, including Lauderdale and Rae at the beginning of the $19^{\text {th }}$ century, have expressed disagreement.

What is the scientific status of the division of labor theory in economic science? According to Schumpeter, the theory is not scientific:

The layman's knowledge that rich harvests are associated with low prices of foodstuffs or that the division of labor increases the efficiency of the productive process are clearly prescientific and it is absurd to point to such statements in old writings as if they embodied discoveries. The primitive apparatus of the theory of demand and supply is scientific. (Schumpeter, 1954, p. $8 ; ; 1959$, p. 9)

Perhaps Schumpeter's reticence is founded; however many classical economists regard the division of labor as a base for their knowledge. In this article we consider whether the division of labor is scientific or literary, or both. We foealisefocus on the first chapter of the Wealth of Nations, so as to analyze deeplyin depth First we examine-itsthe style and its structure of the first ehapter of the Wealth of Nationslike as as a literary text. We then analyze the logical structure of this first chapter. Taking this chapter in isolation is a limitation of this study because the concept of division of labor is also outlined elaborated in the rest of the book. Next we study criticisms expressed by some $19^{\text {th }}$ century economists. Finally, we collate three examples of situations where the division of labor may be tested: actual pin-making in the $18^{\text {th }}$ century, silk manufacture in the $19^{\text {th }}$ century and the Ford car production assembly line in the $20^{\text {th }}$ century. Does the division of labor lead to increased productivity in these real cases? We will conclude by considering some of the facts mentioned, which are certainly true.

\section{The rhetoric of the first chapter}

The first chapter of the first book of the Wealth of Nations is very short, only 3,471 words. It is composed of eleven paragraphs. Adam Smith wanted to persuade his readers through reasoning and seduction.

The macro structure ... seems to follow a pattern. This consists in a single-paragraph introduction that sets out the topic or proposition that is to be explored in the chapter. The rest of the chapter consists of the justification of the proposition. (Henderson, 2006, p. 91)

In writing his text, Adam Smith follows his own stylistic advice:

If there be but one proposition necessary to be proven, there can be nothing more simple; the best method here 
undoubtedly is; $1^{\text {st }}$ To lay down the proposition, and afterwards advance the Several arguments that tend to prove it; which may be summed up, or brought to conclude in the same terms as the Proposition. It is proper to begin with laying down the proposition, as the arguments advanced will by that means make a greater impression on the mind, as it is evident at what they point, than if they were delivered without informing us what was to be the conclusion.-But it will often happen that in order to prove the capital proposition it will be necessary to prove several subordinate ones. In this case we are first to lay down the proposition, and then show in what manner the truth of it depends on that of some other propositions, and having proven these sum up the whole as before. (Smith, 1963, Leeture XXY1983, p. 142)

In order to achieve his aim, Adam Smith thus uses various rhetoric devices, which we will examine first, paragraph by paragraph.

$\S 1$ The greatest improvement ... Adam Smith exposes, in one sentence, the theory which he wants to demonstrate. This is an example of exordium, "in which the orator briefly explains the purpose of his discourse and what he intends." (Smith, 1963, Leeture XXIX1983, p. 179). The sentence is short and jerky, with 5 commas for just 39 words. This fragmentation technique reinforces the authority of the sentence, even though the verb "seem" introduces a degree of doubt.

$\S 2$ The effects of the division of labour ... Adam Smith states that he is going to explain his theory by means of an example. However, he excludes major industry from his analysis. Stating that he will leave large-scale industry aside, he is therefore required to present a small-scale one. This is an example of apophasis. Perhaps Smith wishes to hide the fact that he is referring to the textile industry, the main industry at that time, for he does not give its name. This is a periphrasis. Each paragraph anticipates objections which are likely to arise later. This stylistic device is called a prolepsis (foreseeing and forestalling objections in various ways). Thus Smith prepares the reader for his specific choice of example, that of the pin-making industry.

§3 To take an example ... Pin-making is at the heart of the confrontation between theory and facts. Adam Smith bases his analysis on the descriptions published in France, in Diderot's Encyclopédie as well as in other publications, including those by the Paris Academy of Science. The manner in which the operations are listed creates the impression that Adam Smith is entirely familiar with pinmaking, although the list is incomplete. In rhetoric, the name of "division" is given to this method of amplifying or of clarifying by describing a whole and its constituent parts, or the parts that make up a whole.

These Divisions and Subdivisions are very useful not only in such didactic writings as have in view the Proof of a Single proposition, but even in those where the Design is to Deliver a System of any Science e.g. Natural Philosophy. (Smith, 19963, teettre XXIV1983, p. 144)

The facts are described in a vivid manner. The reader has an illusion of reality (enargia), and this effect is reinforced by the clause "I have seen a small manufactory." Such direct testimony is difficult to contest. Furthermore, the comparative approach is convincing. When division of labor is implemented, physical productivity is very high, whereas without division of labor it would be very weak, and the difference is very considerable, a factor of 240. This structure of thought in opposition (antithesis) is effective thanks to the balance of ideas, which are backed up by the reference to reality.

$\S 4$ In every other art and manufacture ... Adam Smith generalizes his theory. He gives it a mathematical appearance ("proportionable"), as seen in the quotation at the beginning of this text. This literary use of mathematics is highly rhetorical because the statement is not explored elsewhere. Adam Smith offers other examples taken from different professions:

"farmer/manufacturer," "trades ... in each branch of the linen and woollen manufactures." The conclusion concerns agriculture, where division is less frequently implemented and where productivity is lower. This paragraph is the longest one, containing 765 words. 
$\S 5$ This great increase of the quantity of work ... This short paragraph introduces the causes underlying the effects of the division of labor, causes which act independently. Adam Smith brings the reader back to a classic logical construction: causes and effects. The division of labor causes three effects and each effect causes an increase in productive power. The magic number three (tricolon) increases the persuasive power. "Swift proposed a panegyric on the number three and this was one of the articles of its commendation. There is undoubtedly something in this number that makes it more agreeable than others." (Smith, 1963, Leeture XXIV1983, p. 143). Three logical independent points serve to reinforce the initial theory, because if only one of them is right that is sufficient to validate the law.

$\S 6$ First, the improvement of the dexterity ... Adam Smith's argument concerns trades, taking the example of nail-makers. Again, he reasons in the same way as with the pin-makers. Daily production per worker increases from two hundred nails to two thousand, three hundred nails. The facts cannot be doubted because Adam Smith refers to first-hand visual evidence: "The rapidity with which some of the operations of those manufactures are performed, exceeds what the human hand could, by those who had never seen them, be supposed capable of acquiring." (Smith, 1776, Book 1, Chapter 1981, p. 18 HolVl. 1).

\$7 Secondly, the advantage which is gained by saving the time ... Adam Smith evokes the unspecialized country workman who perpetually changes work, going from one task to another. This peasant exhausts himself by going back and forth between his field and his loom. The details of the case make it lively and the reasoning thus becomes more convincing.

$\S 8$ Thirdly, and lastly, every body must be sensible ... "the proper machinery ... facilitates and abridges the labour." The invention of machines depends on the prior division of labor. Adam Smith starts a form of paralipsis: "It is unnecessary to give any example" but then he actually gives one, that of the boys employed in the first fire-engines to alternately open and shut a valve. This pleasant story is a digression aimed at entertaining the readers.

$\S 9$ All the improvements in machinery ... Adam Smith speaks of the emergence of the trade of machine-builders, who are dedicated to progress. This topic provides him with an opportunity to flatter the readers, suggesting that they are not manual workers, but "philosophers or men of speculation." This digression, like parabasis in Greek comedy, serves to captivate the readers.

$\S 10$ It is the great multiplication of the productions ... Adam Smith speaks in praise of the plentiful goods which are produced and consumed thanks to the division of labor. He uses very positively connoted words: "great multiplication of the productions," "well-governed society," "universal opulence," "great quantity of goods," "abundantly," "general plenty." He makes it clear that this opulence concerns all members of society, through the repetition of "every workman." This is an instance of anaphora.

$\S 11$ Observe the accommodation ... Adam Smith reinforces his demonstration using two elements. On the one hand he repeats the idea of the separation of trades, while on the other hand he compares uncivilized society, as a foil, and civilized society with the division of labor. The trades linked to the making of a woollen-coat form a hypnotic hurricane of about 30 nouns relating to trades and 30 nouns relating to everyday or industrial objects. The rhetorical effect of this amplification is speectacular. The author's pleasure is passed on to the readers: indeed Dugald Stewart was most impressed and quoted the entire paragraph: "These illustrations of Mr Smith's are so happily and beautifully expressed, that I thought I could not do them justice in any other way than by transcribing them at length from his work." (Stewart, 1855, p. 325 Vol. 1, Book 2, Ch. 1, Seet. 1). Mark 
Blaug assesses "the last magnificent paragraph of Book 1 Chapter 1-a beautiful example of the eighteenth-century prose" (Blaug, 1964, 19621997, p. 35). Gavin Kennedy also concludes that Adam Smith "displays emphatic and unusual excitement by placing exclamation marks at the end of three consecutive sentences." (Kennedy, 2008, p. 104). Actually Adam Smith advised avoiding the use of exclamation marks. "All exclamations ... would not suit with the impartiality he is to maintain and the design he is to have in view of narrating facts as they are without magnifying them or diminishing them." (Smith, 1963, Leeture XVH,1983, p. 101).

Taken as a whole, this first chapter convinces the reader by means of the accumulation of examples, which are either thoroughly examined, like the pin-makers, the nail-makers or the woollen coat, or more allusively mentioned, through the use of the names of trades or objects. William Henderson remarked upon the numerous examples which Adam Smith had used to convince the reader (Henderson, 2006, p. 91).

Adam Smith emphasized his point by repeating the same idea using many different kinds of exposition (expolition). The Ciceronian structure "docere, placere, movere" (to teach, to please, to move) underpins these variations on the same theme. The logical arguments (to teach) are placed at the beginning in the three first paragraphs. The division of labor is demonstrated by reasoning. Next Adam Smith uses anecdote, with examples from the trades, to entertain readers in the six following paragraphs (to please). Quoting the intellectual profession (philosophers), Adam Smith also attempts to win the readers' favor. Finally, the last two paragraphs stir the reader by using a noble style, amplification, and exclamations (to move). Logos, ethos and pathos are thus used by Adam Smith in the same way as they would have been by a classical writer, with great success. Smith was, of course, very familiar with classical rhetoric.

The Wealth of Nations is a rhetorical work. For D. Mc Closkey, this is not remotely surprising. Economics arguments ... contain elements of persuasion, belief, introspection, appeals to authority and aesthetics. ... The workaday method of economic scientists is in fact literary, since scientific papers, for example, are literary, a pretty obvious remark when you recognize that the scientific paper is of course a literary genre, with an actual author, an implied reader, a history, and a form. (McCloskey, 1986, p. 98)

The reasons to do a rhetorical analysis of an economic text are various: to understand it, to admire it, to debunk it, to set it beside other works of persuasion in science, to see that science is not a new dogma but is thoroughly and respectably a part of the old culture. (McCloskey, 1996, p. 19)

\section{Adam Smith's errors of logic}

Adam Smith taught rhetoric at Edinburgh University_for three years, and logic at Glasgow University for one year. But we don'tdo not have a copy of his lectures inon logic. In the first chapter of the Wealth of Nationshis rork, he aims to convince the reader using logical reasoning, demonstration, and argumentation. The vocabulary of scientific logic recurs frequently in the first chapter: "all" (21 times), "every" (19), "common" (11), "therefore" (9), "always" (8), "general" (7), "necessary" (7), "often" (6), "impossible" (5), "only," "indeed" and "never" (4 each). Adam Smith intentionally takes up a scientific position. This text must therefore be considered as a rational text and as such its truth may be disputed. The first question is that of consistency. Is the text consistent? Are the rules of logic respected?

Behind the rhetoric, are there any sophisms? Adam Smith uses a lot of hedging words like "or" (21 times), "could" (9), "perhaps" (8), "seldom" (4), "certainly" (3), "seem" (3) and "probably" (1). By hedging, the author creates an impression of imprecision, in order to thwart all attempts to falsify his theory (Henderson, 2006, p. 98). Why did Smith lack confidence? Did he detect a weakness in 
his theory? We will analyze below five aspects of illogical reasoning through a-with reference to a classicat text in logic, this one-published by, as defined by John Stuart Mill in 1843. The-Mill's book, Principles of Political Economy, steceeded in 1848 to the replaced the Wealth of Nations in 1848 as one of the most widely read of all books on economics. Mill identified many logical mistakes in reasoning: consequences, contradiction, ambiguity, mis-observation, and false features for the of imaginary_reality_(Mill, 1843, Book V, Chapter VI).

\subsection{Consequences}

John Stuart Mill stated that, "If the consequent be false, the antecedent is false; but this, if the consequent be true, the antecedent is true, by no means holds good, but is an error corresponding to the simple conversion of a universal affirmative." (Mill, 1843, Book V, Chapter VIp. 433 volVol. 2). The error goes from consequences to the premises but the truth does not.

Adam Smith wrote "The separation of different trades and employments ... seems to have taken place, in consequence of this advantage [increasing the productive power of labor]" (Smith, 1776, Bok 1, Chapter 1, 1981, p. 15 Vol. 1§4). All readers agree that many professions exist. For Adam Smith, this is a consequence of his theory. However, the truth of this consequence does not prove the antecedent, as Stuart Mill said. This is clearly not a sound logical argument. Maybe other causes are believable, like the duration of apprenticeship.

The analysis of machines is similar: there is a real fact and a hypothetical cause. "Every body must be sensible how much labour is facilitated and abridged by the application of proper machinery" (Smith, 1776, Book 1, Chapter 1, 1981, p. 19 volVol. 1§8). Adam Smith said this fact was the "consequence of the division of labour." "Some one ... of those who are employed in each particular branch of labour should soon find out easier and readier methods of performing their own particular work." This "cause" is not proven.

This reasoning should not be confused with reasoning by induction.

Induction, then, is that operation of the mind, by which we infer that what we know to be true in a particular case or cases, will be true in all cases which resembles the former in certain assignable respects. In other words, Induction is the process by which we conclude that what is true of certain individuals of a class is true of the whole class, or that what is true at certain times will be true in similar circumstances at all times." (Mill, 1843, Book HI, Chapter Hp. 352 volVol. 1)

Adam Smith quotes particular cases, like "different trades and employments," whereas induction would involve saying that all trades are divided into professions.

\subsection{Contradiction}

John Stuart Mill said:

Fallacy of changing the premises: Perhaps, however, the commonest, and certainly the most dangerous fallacies of this class, are those which do not lie in a single syllogism, but slip in between one syllogism and another in a chain of argument, and are committed by changing the premises. A proposition is proven, or an acknowledged truth laid down, in the first part of an argumentation, and in the second a further argument is founded not on the same proposition, but on some other, resembling it sufficiently to be mistaken for it. (Mill, 1843, Book V, Chapter VIp. 435 Vo1Vol. 2)

One of Adam Smith's sentences is rather surprising: "Though in [the great] manufactures ... the work may really be divided into a much greater number of parts ... the division is not near so obvious, and has accordingly been much less observed" (Smith, 1776, Bok 1, Chapter 1, p. $\$ 214$ vetVol. 1). When the phenomenon occurs on a wider scale, it becomes less easily observable. This is a strange phenomenon indeed! It is nonetheless possible that this paragraph aims to dismiss the 
textile industry. It is well known that Adam Smith missed the industrial revolution. In textile factories several identical machines operated side by side on the same operation and the full process was divided amongst several buildings, which each specialized in one operation. So the intra-firm division of labor would be unobservable inside a single building.-

\author{
2.3 Ambiguity \\ John Stuart Mill said: \\ The source of error is the ambiguity of terms: when something which is true if a word be used in a particular \\ sense, is reasoned on as if it were true in another sense. (Mill, 1843, Book V, Chapter VHp. 440 volVol. 2)
}

Fallacies of Confusion ... have their source in language, whether arising from the vagueness or ambiguity of our terms, or from casual associations with them. (Mill, 1843, Book V, Chapter Ip. 342 viVol. 2)

In the first sentence, the theory uses five concepts, none of which is formally defined. Two of them disappear in the following text: "skill" and "judgement."

The "productive powers of labour" seem to be the number of units produced in a day by each worker, "four thousand eight hundred pins in a day" (Smith, 1776, Book 1, Chapter 1, 1981, p. 15 vol-Vol. 1§3). Dexterity is measured in the same manner, "two thousand three hundred nails in a day" (§6). What is the distinction between the two concepts? Perhaps "dexterity" refers to ability and the "productive powers of labour" to the concrete result. But then the causality ( $\$$ ) between dexterity and high production is only a tautology.

The "division of labor" is the most important concept, but it is ambiguous. There are four definitions.

First the division of labor is a means of organizing the workshops where the workers are specialized in specific operations $(\S 3)$. These operations may be subdivided: "The different operations into which the making of a pin, or of a metal button, is subdivided" ( $\$ 6)$. "The work may really be divided into a much greater number of parts" $(\$ 2)$. The process of dividing is endless but "in many [manufactures], the labour can neither be so much subdivided, nor reduced to so great a simplicity of operation" ( $\$ 4)$; "those manufactures in which labour is most subdivided" ( $(8)$.

Secondly, the division of labor is a measure, the degree of the "division of labor." In the quantitative version of the theory: "The division of labour, [or the increasing of the degree of the division of labour] ... occasions ... a proportionable increase of the productive powers of labour" $(\S 4)$.

Thirdly, the division of labor is also the act of dividing "This great increase of the quantity of work which, in consequence of the division of labour [the act by which the labour is divided]" (§5). The same meaning is used in this sentence "the division of labour ... necessarily increases very much the dexterity of the workman" (§6).

Finally, the division of labor is the "separation of different trades and employments" (§4), the distinction between professions.

The division of labor is also a historical change. "In the progress of the division of labour, the employment ... comes to be confined to a few very simple operations, frequently to one or two." (Smith, 1776, Book V, Chapter 1-1981, p. 781 vol-Vol. 2). The concept of the division of labor stretches out from a start to an end, from the simplest instance, the emergence of the professions, to the most complex, specialized labor. The extension of the concept corresponds to the expansion of the most repetitive labor.

So the division of labor is an ambiguous concept. Adam Smith says that specialized labor and separate professions have the same conceptual foundations and the same effects. This is in fact not necessarily the case. 


\author{
2.4 Mis-observation \\ John Stuart Mill said: \\ It is non-observation, when all the error consists in overlooking, or neglecting, facts or particulars which ought \\ to have been observed. ... Non-observation may either take place by overlooking instances, or by overlooking \\ some of the circumstances of a given instance. (Mill, 1843, Bok V, Chapter IVp. 387 volVol. 2)
}

Adam Smith (Smith, 1776, Book 1, Chapter 1, 1981,p. 18 vol-Vol. 1\$6) compares three situations: (i) "A common smith, who, though accustomed to handle the hammer, has never been used to make nails," (ii) "A smith who has been accustomed to make nails," (iii) "Several boys under twenty years of age who had never exercised any other trade but that of making nails ... exerted themselves." The daily production is 200 or 300 nails for the first, 800 or 1000 nails for the second, 2,300 for the third, i.e. respectively 3 minutes, 45 and 16 seconds per nail.

Apparently, the third situation, which is the most specialized, is also the most productive and therefore the best. The example appears realistic. Adam Smith says "I have seen ..." But why is this third situation not the only one? What are the circumstances?

The first smith

who, though accustomed to handle the hammer, has never been used to make nails, if upon some particular occasion he is obliged to attempt it, will scarce, I am assured, be able to make above two or three hundred nails in a day, and those too very bad ones. (Smith, 1776, Book 1, Chapter 1,1981, p. 18 Vol. 1)

What is this particular occasion? How many nails does he make? Ten in half an hour?

The second person is not a nail maker, he has another "sole or principal business." What is this business? Why does he make nails? How many nails does he make? One hundred in one hour? Were the nails standard or particular? Diderot's Encyclopédie describes about 30 kinds of nails, which were made in several sizes. They were heated once or several times (Diderot, 1753, Volumel. 3, Article "Clou" and 1763, Volume 3 of the plates, article "Cloutier").-

Was the third smith selected for his high level of production?

Why don't the first two smiths give the work to the third? What are the wages for nail making? What are the tools? Diderot's Encyclopédie describes 10 tools including the nail-box, specially designed for nail making, and a metallic spring to eject the nail after it was ready.

Why isn't the nail-smith's labor divided? Three workers are shown in the plate of Diderot's Encyclopédie. One man is putting the iron in the fire, another is forging the body of the nail and a third hits the head of the nail. But in fact, the same smith probably carried out the three operations.

It is difficult to understand how, at the same time, in the same place, three smiths worked with so great a difference in productivity, a factor of 11.5. Adam Smith would have to describe the circumstances in which the three simultaneous organizations of labor were possible. Although he well knew the nails making in Kirekaldy was extremely familiar with nail-making in Kirkcaldy, he didn't give the details to understand- provide sufficient details to demonstrate why the three situations were-in the same time- simultaneously observable. It is likely that the first two situations are fictitious, or "hypothetical," as William Henderson says (Henderson, 2006, p. 90).

Next, Adam Smith compared this real pin making with the case of apprenticeship. "A workman not educated to this business ... nor acquainted with the use of the machinery employed in it ... could ... make one pin in a day, and certainly could not make twenty" (Smith, 1776, 1981, p. 14 vol-Vol. 1). Adam Smith didn't observe this situation but he assumed thethat production was very low and webelieve that this seems to us to be a plausible assumption-(???)f. Two features were different in 
this case, the no-unspecialized labor and the training. Adam Smith chose to explainascribe the low production byto the no absence of specialization but during apprenticeship the-production is always low (Peaucelle, 2005). He forgot the main feature, which was the main explanation.-

\section{theler emparison,}

\subsection{Imaginary Rreality with false features}

John Stuart Mill said: "It is mal-observation, when something is not simply unseen, but seen wrong." (Mill, 1843, Book V, Chapter_IV.p. 387 volVol. 2).

Here is another one of Adam Smith's errors of logic: the ereation ofadding features to the reality. If the reasoning by induction is grounded in partly imaginary facts, this is not proof. Adam Smith himself said "The facts must be real. ... Feigned Events and the causes contrived for them, as they did not exist, can not inform us." (Smith, 1963, Leeture XVII,1983, p. 91).

Adam Smith created the impression of reality through his stylistic devices. He added "I have seen a small manufactory of this kind" (Smith, 1776, Bok 1, Chapter 1, 1981, p. 15 Vol. 1§z). As an eyewitness, his observations cannot be contested. But all the knowledge which he gathered on pinmaking came from four French texts including the-Diderot's Encyclopédie and a publication-of by the Academy of Sciences (Peaucelle, 2006). It is indeed quite possible that Adam Smith never saw any small pin-making factories, and that he saw the labor rate in Macquer's Dictionnaire

portatifdietionary (Macquer, 1766). It eould /should???] be noted that Smith owned a copy of this book, as indicated in Mizuta's Catalogue of Adam Smith's Library (1967, p. 116). Here are four arguments to support this theory:

a) If Adam Smith had inquired in the field about the quantity of pins made by ten people, and if he had found the same figures as the figures presented in Macquer's dictionary, he would have been extremely astonished and could not have hidden his surprise;

b) Which workmen would be found in a workshop of 10 people visited by Adam Smith? According to Macquer's figures, there would be the following staff: 5.6 head makers and 1.6 putters. There were 7 women for these two operations. 7 women out 10 workers: this ratio is remarkable. Adam Smith speaks neither about women, nor about French encyclopaedists. The 3 other workmen would presumably have carried out the 16 other operations. They would not have been very specialized;

c) Adam Smith describes a strange fifth operation: “"a fifth grinds [the pin] at the top for receiving the head'”- ( $(3)$. Why grinding-grind the top before it received thepin head? The rounded end would be flattened with the head. An-Eearlier grinding was thntessfusetessfunnecessary???]. According to the Encyclopédie (Diderot, 1765, Volume 3 of the plates. Article "Epinglier" [pin maker] by Perronet), the wire was cut into sections. The length of a section was the length of 2,3 or 5 pins. The pointer held easier the section more easily, and-made a point at the-both ends and then worked another fine point. pointed finely again.After pointing, the section was cut at the pin length. Smith's technical mistake here is inconceivable if he had actually visited a workshop;

d) Where can Adam Smith have carried out his visit? In France, the only site of production was Laigle in Normandy. He did not visit Laigle. During his travels to France, that would have represented a detour of $200 \mathrm{~km}$ on his journey between Paris and Bordeaux, and he did not go there. In England, pins were manufactured in Gloucester and Bristol. Arthur Young visited this area and he quoted the productivity figures:

The wires are cut into them [pins] and compleated here, employing a great number of girls, who with little machines, worked by their feet, point and head them with great expedition; and each will do a pound and half in a day. The heads are spun by a woman with a wheel, much like a common spinning wheel, and then separated from one another by a man, with another little machine like a pair of shears. (Young, 1768 , pp. 184-85) 
If we count 4,000 pins for a pound, like Adam Smith (Smith, 1776, 1981, p. 15 volVol. 1), theBristolproduction in Bristol was 6,000 pins per person-and per day. Young's figures in Gloucestershire aren't Smith's figures (4,800 pins per person-and per day). The productive powers were different. Adam Smith therefore did-n'et write abouteberve pin manufacturing in this Englisht area of England.

It seems Adam Smith did not visit a pin-making workshop, but his figures, 4,800 pins in a day, are is roughly correct as roughly the productive power in Normandy.-

Next, he compared this reality with an imaginary reality. He imagined the situation whereby someone teaches workers how to manufaeture pins. "A workman not edueated to this business ... nor aequainted with the use of the maehinery employed in it ... eould ... make one pin in a day, and eertainly could not make twenty" (Smith, 1776, Book 1, Chapter 1, §3). Pins are never made in this sittation, except during apprenticeship. Adam Smith thus compares reality with a fantasy (Peancelle, 2005).

Eatterdale had seen that the compared sittations were false but he responded to this sophism with another sophism. He compare two other imaginary sittations. The result is anything but eonvineing.

Adam Smith used real ereated other imaginary examples but he added imaginative features. InAt this time, $;$ the there was the "country weaver, who cultivates a small farm" (Smith, 1776, 1981, p. 18 vol-Vol. 1)(\$7). But he didn't- "lose a good deal of time in passing from his loom to the field, and from the field to his loom."- In reality, he did not go ceaselessly from fields to loom like a shuttle. Every day, he chose his occupation in accordance with the seasons and with the weather:the loom during the winter and the field during the summer. Without specialisation, he didn't lose time. The lost time is imaginary. Of course, the mixture of reality and fantasy is a cause of error in the reasoning.

The bright style of this first chapter hides its logical errors. The truth of the theory is not ascertained. Globally, the reasoning on division of labor increasing physical productivity is not established. The direct demonstration about pin-making does not prove the theory because Adam Smith compares a real case with an imaginary one. Then the three so-called "causes" are wrong. The first repeats the previous reasoning with the comparison of false cases with a real case of nail making. The second "cause" is supported by the fietitious situations of the country weaver, but as we have noted, the latter he-didn't go from loom to fields like a shuttle- all day long-during the all day. The third "cause" uses the fact of the increase of production thanks to machinery. This fact would be a consequence of the division of labor, supporting the invention of machines, but logically the truth of the consequence is not a proof of the premise. Adam Smith used this logical fallacy another time, in relation to the separation of professions. He thought that this separation was a consequence of his theory. But logically the antecedent isn't true if a consequence is true. Behind the appearance of logic, the division of labor as a way to increase the productive power of labor is poorly proven.

If Adam Smith's theory is true, when two workers carry out the same operation, it is advantageous to divide labor, and each worker operates a repetitive half labor. No workers have the same tasks in the same factory. No profession exists in the same area. This consequence is not observed. This legitimate mode of reasoning is called a "reductio ad absurdum" (reduction to the absurd).

George Stigler saw the contradiction between both of Adam Smith's laws:

When Adam Smith advanced his famous theorem that the division of labor is limited by the extent of the 
market, he created at least a superficial dilemma. If this proposition is generally applicable, should there not be monopolies in most industries? So long as the further division of labor ... offers lower costs for larger outputs, entrepreneurs will gain by combining or expanding and driving out rivals. And here was the dilemma: either the division of labor is limited by the extent of the market, and, characteristically, industries are monopolized or industries are competitive, and the theorem is false or of little significance. Neither alternative is inviting. ${ }^{1}$ (Stigler, 1951 p. 1851950)

\section{The debate on the division of labor}

Adam Smith's first chapter has a rhetorical structure which hides the logical failures._Many economists agree with this chapter, like the NobleNobel prize-winners Milton Friedman, Ronald Coase, Robert Mundell, and Edmund Phelps. At the beginning of the 19th century, it became possible to contest the fresh theories of the "father of economics" and four economists opposed Smith's division of labor.

\subsection{Lauderdale}

Lord James Maitland, $8^{\text {th }}$ Earl of Lauderdale, who was a Francophile and admirer of Quesnay, comments on and criticizes Adam Smith's work. He contests the example of pin-making, stating that high production depends only upon the tools used:

One man, with the use of this machinery, though the goes through and performs all the operations himself, must, obviously, manufacture more pins in an hour than would be formed in a month, or even in a year, by any number of men amongst whom the labour could be divided, if unaided by the circumstance of part of their labour being supplanted and performed by capital. (Lauderdale, 1804, pp. 286-87)

The principal progress is the invention of tools.

The history of man shows us, that the simplest and most efficacious machines for supplanting labourinstruments with which habit has so familiarized us, that we hardly dignify them with the name of machinery - are introduced at an early period of society when the division of labour is comparatively unpractised and unknown for the purpose of supplanting the personal labour of man in the conduct of agricultural industry. (Lauderdale, 1804, pp. 291-92)

The use of machines in the industrial process has a counterpart in economic terms. Capital partially supplants labor. This idea was adopted by subsequent economists.

It is in truth the great and distinguishing advantage which man possesses of supplanting and performing labour by capital; in conjunction with the power of directing his labour to the increase of the quantity, and melioration of the quality, of the production of nature ... which form the means of procuring the wealth and the comfort enjoyed by civilized society. (Lauderdale, 1804, p. 287)

It is amply to be found in every statement that ever came from any man practically concerned in any branch of manufacture; as it is uniformly to the introduction of some sort of machinery, to the effects of the application of chemistry to manufactures, or to the increase or command of capital enabling the manufacturers to reduce the price, and by this means creating an augmentation of demand, to which the extension of sales is attributed. (Lauderdale, 1804, pp. 288-89)

Lauderdale also provides a detailed example: Scottish spirits manufacturers worked 22 times faster in 1799 than in 1785, without any division of labor.

\subsection{Brougham}

Baron Henry Brougham refutes Lauderdale's arguments. He comes back to question of the division of labor, but combines it with that of the invention of machines:

The use and invention of machinery present, in fact, the more remarkable example of the advantages derived from the division of labour. To contrast the benefits received from this division with those produced by the use of machinery, is as absurd as to compare the effects of two circumstances intimately and necessarily connected; the one, in fact, the immediate result of the other, and both inseparably joined together in all their operations. It is like quibbling and disputing whether fire or gunpowder produce the greatest augmentation in the aggregate of killed and wounded. (Brougham, 1805, p. 372)

1 Here it is possible in logic for both theories to be false. 


\subsection{Stewart}

Dugald Stewart was one of Brougham's teachers at the University of Edinburgh. In 1785 he succeeded Adam Ferguson as Chair of Moral Philosophy. First, he sees a limit to the division of labor, other than the extent of the market: fatigue, or physiological reasons:

That the rapidity of the hand in executing a mechanical operation may be increased by practice to a very great degree is an acknowledged fact. But there is obviously a limit, beyond which this rapidity cannot possibly be carried; and I am inclined to think, that in such very simple operations as drawing out a wire, \&c., it is not very long before this ultimatum in point of rapidity is reached by the workman. Nor can I bring myself to believe, that after it is attained, the dexterity of the workman in performing this one operation would be at all impaired, though he should also have acquired a few other accomplishments of a similar nature: that the drawer of the wire would be less fitted for his employment, if he changed occupations for a day or two with the cutter or pointer of the pin. (Stewart, 1855, p. 314 Vol. 1, Book Seeond, Chapter I, Seet. I, Stbsection "On the Divisionof Labour.")

That leads Stewart to agree with Lauderdale in his criticism of Adam Smith:

I entirely agree with a remark of Lord Lauderdale in his Inquiry into the Nature and Origin of Public Wealth, where he observes, that even in the trade of the pin-maker, without the use of machinery to supersede the work of the hand, no great progress could have been made in the rapidity with which pins are formed. ... The two first reasons are certainly legitimate and satisfactory, so far as they go; but in his third reason, Mr Smith has plainly departed from his usual logical accuracy. The tendency of the division of labour to promote the invention of useful machines cannot with propriety be said to render that labour more effective, so long as it continues to be exerted; for as soon as the machine is invented, the labour is superseded altogether... The effects of the division of labour, and of machinery in the manufacturing arts, are produced on principles entirely different. ... They are often so combined as to render it difficult to draw the line between their respective functions. (Stewart, 1855, p. 315 Vol. 1 "On the Use of Machinery as a Substitute for Labour.")

But Stewart was cautious not to contest the master outright.

I do not censure his doctrines as erroneous, but only as partial and incomplete. ... The division of labour ... may operate as one cause of the improvement of the arts ... yet that a variety of other causes co-operate no less powerfully to the same effect; more particularly the invention of machinery, the application of chemistry to the arts, and the facilities afforded to commercial exchanges by roads, bridges, canals, harbours, and the arts of navigation ... I mean their tendency to save or to supersede labour; and therefore I should be disposed to substitute, instead of the phrase 'division of labour,' as employed by Mr Smith, the more general phrase, 'economy of labour.' (Stewart, 1855, p 331-32 Vol 1"On the Use of Maehinery as a Stubstitute for Labeut.")

\subsection{Rae}

John Rae was born in Scotland but spent a long time in Canada, where he worked as a schoolmaster, and in Hawaii, where he was a medical inspector. Curiously he published a book criticizing Adam Smith's theory:

In the Wealth of Nations, the division of labour is considered the great generator of invention and improvement, and so of the accumulation of capital. In the view I have given it is represented as proceeding from the antecedent progress of invention, and increase of stock, and as operating chiefly by quickening the exhaustion of instruments, and so placing them in orders of more speedy return. (Rae, 1834, p. 352Appendix to Book H)

In Rae's view the division of labor arises from the intensive use of machines:

If any man had all the tools which these several occupations require, at least three fourths of them would constantly lie idle and useless. It were clearly then better, were any society to exist where each man had all these tools, and alternately carried on each of these occupations, that the members of it should if possible divide them amongst them, each restricting himself to some particular employment. (Rae, 1834, p. 164Chapter VIII)

\subsection{Marshall andNathan Rosenberg}

At the end of the XIXe century, Alfred Marshall widely developed the theory of the division of labor. He added the concept of specialisation in the same area.

This elementary localization of industry gradually prepared the way for many of the modern developments of division of labour in the mechanical arts and in the task of business management. (Marshall, 1890, IV.X.2) 
The economic use of expensive machinery can sometimes be attained in a very high degree in a district in which there is a large aggregate production of the same kind, even though no individual capital employed in the trade be very large. For subsidiary industries devoting themselves each to one small branch of the process of production, and working it for a great many of their neighbours, are able to keep in constant use machinery of the most highly specialized character, and to make it pay its expenses, though its original cost may have been high, and its rate of depreciation very rapid (Marshall, 1890, IV.X.8) The full economies of division of labour can be obtained by the concentration of large numbers of small businesses of a similar kind in the same locality (Marshall, 1890, IV.X.21) Moreover Marshall followed the former ideas about the link between innovation of machines and division of labor but he distinguished the two factors.

The two movements of the improvement of machinery and the growing subdivision of labour have gone together and are in some measure connected. It is the largeness of markets, the increased demand for great numbers of things of the same kind, and in some cases of things made with great accuracy, that leads to subdivision. of labour; the chief effect of the improvement of machinery is to cheapen and make more accurate the work which would anyhow have been subdivided. (Marshall, 1890, IV.IX.10)

More recently Rosenberg views the division of labour as closely linked to the invention of machines: "Smith's long-term prognosis for capitalism is centred upon its capacity for generating technical change and thus substantially raising per capita income." (Rosenberg, 1965, p. 128) -Adam Smith thought the inventions are made either by the specialized worker himself or by engineers called "philosophers or men of speculation," a specialized profession.

Originally, therefore, when production involved a relatively simple technology, increasing division of labour, by sharpening and concentrating the focus of a worker's attention, made it easier for him to invent and to institute non-fundamental improvements within the existing technology. As the technology becomes increasingly complex however, and as the solutions to problems require the ability to draw upon sources of knowledge and experience from a wide range of areas or disciplines, the worker is likely to be increasingly inadequate because of the exceedingly narrow repertory of materials from which he can draw. (Rosenberg, 1965, p. 134)

All of these authors agree that the productive power of labor increases. The cause found is either technical inventions and division of labor working together, or division of labor in the first instance, or else inventions preceding division of labor. There are thus three possible theories. It seems that Adam Smith's is the second; Brougham's, Stewart's, Marshall's and Rosenberg'sRosenberg's, Stewart's and Brougham's is the first; Lauderdale's and Rae's is the third.

But what are the facts underlying these theories?

\section{The facts about the organization of labor}

As Brougham and Stewart noted, facts - diachronic facts - combine the change in technology and the change in the organization of labor. No successive observations inside the workshops are conclusive because the available machines change entlesslycontinually. The observed increase in the intra-firm productive power of labor depends on both compound factors.

But some situations exist where the technology is the same and the organization is different. It is possible, in these few cases, to separate the effect of the division of labor. These cases exist really if the production cost is similar at the same time (i.e. with the same available technology), because the production rates are the same, or because the gap between wages balances the gap between physical productivities. Here is another case, during a very short period, where several organizations are tested, like in Taylor's method. It is three observable real cases of more divided labor with the same technology. 
During the $18^{\text {th }}$ century, pins were made in three countries: in Holland, near Maastricht, in France, near Rouen and in England, near Bristol. The technical processes were similar and were described accurately by the French encyclopaedists. The tools had been invented in Holland two centuries before. Two thirds of the workers were women, but the encyclopaedists did not write about the concrete labor. Small workshops existed, with three workers, as well as bigger ones, with twenty. In all workshops, the workers had the same wages and the same production rate, contrary to Smith's ideas on the division of labor. It is the first observable case, based upon several organisations with the same wages and same productive power of labor.

Charles Babbage read Perronets's original description of pin-making in France (Diderot, 1765, Volume 3 of the plates. Article "Epinglier" [pin maker]). He noted "that the wages earned by the persons employed vary from $4-1 / 2 \mathrm{~d}$. per day up to $6 \mathrm{~s}$., and consequently the skill required for their respective employments may be measured by those sums." The production cost is lower with the division of labor because of the differences of wages.

The higher the skill required of the workman in any one process of a manufacture, and the smaller the time during which it is employed, so much the greater will be the advantage of separating that process from the rest, and devoting one person's attention entirely to it. (Babbage, 1835, p. 186)

Babbage didn't think that division of labor increased the productive power of labor.

After this organisation of labor, in the $19^{\text {th }}$ century, the American engineer Lemuel W. Wright patented the first machine in 1824, an integrated (single) machine. The English manufacturer Daniel Foote-Taylen improved it after 1833.This power driven machinery, monitored by a single worker, combined eight operations. The division of labour decreased but the power of labor increased. This result appears to contradict Adam Smith's theory but he didn't say that machines increase the division of labor, neither by the invention of the worker himself nor by the invention of engineers. Curiously machines provide, in Adam Smith's theory and in actual fact, an opportunity to recombine divided labor.
4.2 The silk industry
Over the first half of the $19^{\text {th }}$ century, Lyon manufacturing consolidated the advantages it had as a collective manufacture, while London manufacturing weakened its position to the extent that it caved in to pressure towards mass production, from which it in fact derived no advantage whatever. ... In London the principle of strong specialization and in Lyon the principle of polyvalence. ... In London nobody doubted the classic 'law' by virtue of which specialization implies greater skill. But in Lyon a completely opposite logic was taken for granted, of a type unknown to the classics of political economy, to the 'philosophy of manufactures' or to industrial evolutionism. (Cottereau, 1998, pp. 95-97)

In the 1830 s, silk workers in Lyon were roughly $70 \%$ more productive, with the same looms. After deregulation in 1826, the wages of the silk workers in London fell drastically and the workers grew very poor. With more specialized work, the British weavers in London had lower productivity and were paid less. Division of labor in the silk industry didn't increase the productive power of labor, quite the contrary. This is the second observable case, showing several organisations where higher wages are balanced by higher productive power of labor.

\subsection{The assembly line at Ford}

According to Taylor's method, the organizer tries several organizations to find the "one best way." The available machinery is the same. The organization, including the division of labor, varies. Sometimes more divided labor is best but this is not a general rule. We have the figures for the invention of the assembly line at Ford.

In 1912, in Detroit, the length of time for assembling a car was 12.5 man*hour per car. In 1913, Henry Ford tried several new methods of organizing labor. First, he experimented with a moving 
team of 6 unspecialized workers along 75 meters. Productivity was 5.6 man*hour per car. Secondly, he tried 140 specialized workers on fixed posts on a line 45 meters in length. Productivity became 3 man*hour per car. Third, he used 177 specialized workers on fixed posts on a line 90 meters in length. Productivity increased to 2.85 man*hour per car. In 1914, Ford built 3 identical assembly lines, with each using 78 specialized workers on fixed posts along the line. Productivity reached 1.55 man*hour per car. (Hounshell, 1984, p. 254-55).

The best way to proceed, with the machinery of the time in Ford's plant, was not to use more specialized labor, but neither was it to use less specialized labor. The size of the market allowed for more divided labor, but highest productivity was achieved with three parallel lines. This is the third observable case, showing several tried and tested modes of organization during a short period before the industrial choice is made to select the most productive one.

So technology was constant in these three real cases. The organizations of labor compared here used the same machines. Physical productivity wasn't highest with the most divided organization of labor inside the firm. Why does the thesis of the single effect of the intra-firm division of labor seem incorrect in these situations? What is false in these examples? Or what adjustments would need to be made to Adam Smith's theory? These arguments do not concern the extra-firm division of labor, "specialisation of industries" as a potential "part of the process by which increasing returns are realised" (Young, 1928).

\section{True historical facts}

From a Popperian perspective (Popper, 1959), Adam Smith would be wrong about the concept of the intra-firm division of labor. However a $\mathrm{A}$ considerable number of arguments and facts, which were used by Adam Smith and his followers, are nenevertethheless true. Here it is important to ascertain what remains true.

Since the Neolithic age, with the birth of agriculture, many distinct trades have been identified. Nobody knows the reasons for this structuring process; they may include the selection of the people involved and the duration of training, economical reasons like efficiency or political reasons, such as the desire to take power and ensure victory during wartime. Regularly, trades disappear, like that of a blacksmith, stevedore, copyist, falconermilliner, eobbler, typist or public letter-writer, and new professions appear, like that of an astronaut or webmaster. This phenomenon is perhaps controlled by an increase in physical productivity.

Various organizations of labor can exist with the same machines. If the wages (i.e. the skills) are varied with the division of labor, the production cost is lower. This is Babbage's argument. Furthermore if a machine is costly, for maximal use a worker or a team are especially dedicated to it. The specialization of the workers on these machines decreases production costs. This is Rae's argument. Labor on expensive machines becomes specialized. Conversely, if machines are cheap, work is no longer specialized. For instance, computers in the 1960s and 70s were very expensive. Specialized staff were used to operate them day and night. Now, with PCs a thousand times cheaper, everyone can buy them, and non-specialized use of the computer has developed. Similarly, cell phones are cheap and anybody can use them to communicate, whereas with $20^{\text {th }}$-century maritime radios a specialized operator was needed on each vessel. Introduction of cheap machines decreases specialization. The cost of fixed machines and varying manpower cost are two economic causes for division of labor. For economic reasons, the organization of labor depends on maehines.

the latest technology, which is not always embodied inby machines. 
The criterion for choosing new machines is cost. Each technological change must lower the production cost per unit for the same quality. The cost of machines must not increase production costs in plants, including when depreciation is factored in. If the new machines are more costly than the previous ones, then physical productivity must increase.

Economies of scale are observed mainly in industry for many causes like the fixed costs, R\&D, knowledge, and technical documentation which do not increase with volumes, therefore cost per capacity unit is inversely proportional to volumes. Another cause is well-known by engineers, it is the physical property of the machines for which the cost and the capacity are not proportional. Machines are typically when there are high numbers of machines. The eauses of these economies of seale are to be found in the strueture of eosts, which is conneeted with physieal phenomena: - pipes-tines infor which, for a given length, (beeause cost (depending on circumference of the

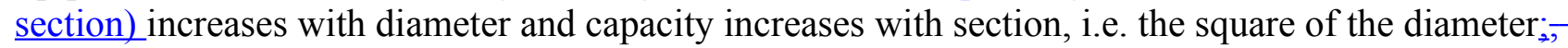
therefore cost per capacity unit is inversely proportional to linear dimension); - tanks, trucks, boats, planes infor which (beeause cost (external surface and resistance to the move) increases with the square of the linear dimension and volumes are cubic proportional:-; therefore cost per capacity unit is inversely proportional to linear dimension); - devices against random (inventories, call centers, etc.) where cost varies with square root of volumes; therefore cost per capacity unit is inversely proportional square root of linear dimension; fixed eosts like R\&D, information and knowledge whieh do not inerease with volumes, thereforeeost per eapaeity unit is inversely proportional to volumes.

Through the ages, in the long term, efficiency increases, in terms of human work (physical productivity of labor), raw materials, energy, land and other resources necessary for production. This historical increase in physical productivity is the compound effect of knowledge, techniques, science, and organization.

The process of the invention of tools and machines is an autonomous process, and a very complex one, where many factors play a part, including science, education, imagination, ambition and economic motivations.

Adam Smith and his followers gathered a lot of true facts which appear to be the consequence of increasing productive power arising from the division of labor. But other theories can explain these facts. The truth of these consequences reveals nothing about the truth of the possible cause. Nevertheless the real facts have a rhetorical effect and simulate logical, rigorous reasoning.

TheOur analysis washas been confined to chapter one of The Wealth of Nations and it may be that other texts by Smith contradict it. perhaps other Smith's texts eontradiet it. Nevertheless

Schumpeter, whom we quoted at the start of this article, was-seems probably right. The division of labor should be considered as falling outside the scientific economic field. Here we have considered only the division of labor inside plants, without technological change, and our conclusions are limited to this topic. But following Adam Smith, the division of labor concept was broadly extended to the division of labour among industries, the locational specialisation, the social division of labor, the international division of labor, the occupational division of labor, the gender division of labor, etc. Perhaps the pin-making example hides the other significations of Adam Smith's theory:

Division of labor may mean the separation of different enterprises and their concentration on the production of single products. This sense of the term soon comes to overshadow the earlier conception. Indeed, the whole of Book I is constructed upon the grand theme of the social division of labour: the economic system is in essence a vast network of interrelations among specialised producers held together by the price system. (Blaug, 1962, 


\section{References}

Babbage C. (1835), On the eEconomy of m Machinery and manufactures. London: Charles Knight.

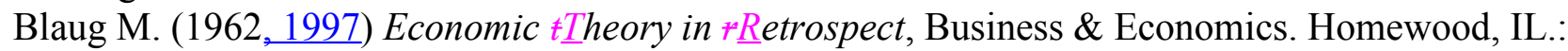
Irwin. Cambridge, NY: Cambridge University Press.

Brougham H. (1805) Thoughts Suggested by Lord Lauderdale's Observations upon the Edinburgh Review. London: Printed for Longman, Hurst, Rees, and Orme.

Cottereau A. (1998), "The Fate of Collective Manufactures in the Industrial World: The Silk Industries of Lyon and London, 1800-1850," in C. F. Sabel and J. Zeitlin, World of Possibilities: Flexibility and Mass Production in Western Industrialization. New York, NY: Cambridge University Press, 75-152.

Diderot D. (1751-1780) Encyclopédie. Paris: Briasson.

Henderson W. (2006). Evaluating Adam Smith: Creating the Wealth of Nations. London, NewYork, NY: Routledge.

Hounshell D. (1984) From the American System to Mass Production, 1800-1932, The Development of Manufacturing Technology in the United States. Baltimore, MD: The John Hopkins University Press.

Kennedy G. (2008), Adam Smith: A Moral Philosopher and Hhis Political Economy. New York, NY: Palgrave Macmillan.

Macquer P. (1766). Dictionnaire portatif des arts et métiers. [Portable Dictionary of Arts and Crafts]. Paris: Lacombe.

Maitland J. $8^{\text {th }}$ Earl of Lauderdale (1804). An Inquiry into the Nature and Origin of Public Wealth and into the Means and Causes of its Increase, Edinburgh: A. Constable.

McCloskey D. (1986). "The Rhetoric of Economics," Social Science 71 (2/3, Fall 1986), 97-102.

McCloskey D. (1985), The $¥ \underline{R}$ hetoric of eEconomics. Madison WI: University of Wisconsin Press.

Marshall A. (1890) Principles of Economics. London, New York: Macmillan.

Mill J.S. (1843), A System of Logic, London: John W. Parker.

Mizuta H. (1967). Adam Smith's library, a supplement to Bonar's catalogue with a checklist of the. whole library. London, Cambridge: Royal Economic Society.

Peaucelle J.L. (2005) "Raisonner sur les épingles, l'exemple d'Adam Smith sur la division du travail," [Reasoning on Pin Making, Adam Smith's Example about the Division of Labor], Revue d'Économie Politique, 4, 499-519.

Peaucelle J.L. (2006), “Adam Smith's Use of Multiple References for his Pin Making Example,” in The European Journal of the History of Economic Thought, 13:4, 489-512.

Popper K. (1959) The Logic of Scientific Discovery. New York, NY: Basic Books (original published 1935).

Rae J. (1834) Statement of Some New Principles on the Subject of Political Economy, Exposing the Fallacies of the System of Free Trade, And of Some Other Doctrines Maintained in the Wealth of Nations. Boston, Mass.: Hilliard.

Rosenberg N. (1965) “Adam Smith and the Division of Labour: Two Views or One?", Economica 32 (126): 127-139. pp. 128 and 134.

Schumpeter J.A. (1954), History of Economic Analysis. New York, NY: Oxford University Press.

Smith A. (1776, 1981). An Inquiry into the Nature and Causes of the Wealth of Nations. Glasgow edition of the works and correspondence of Adam Smith, VotVol. 2. Oxford (Oxfordshire): Clarendon; New York, NY: Oxford University Press. Eondon: Methuen.

Smith A. (19663, 1983). Lectures on Rhetoric and Belles Lettres, ADelivered in the University of 
Glasgow by Adam Smith, $\neq$ Reported by a student in 1762-63. Glasgow edition of the works and correspondence of Adam Smith, VolVol. 4. Oxford (Oxfordshire): Clarendon; Londen, New York, NY: Oxford University PressT. Nelson.

Stewart D. (1855), Lectures on Political Economy. Edinburgh: T. Constable.

Stigler G. (1951日) "The Division of Labor is Limited by the Extent of the Market" in Journal of Political Economy, 59(3): 185-93.

Young A. (1768). A Six Weeks' Tour through the Southern Counties of England and Wales. London: Nicoll.

Young A. (1928), "Increasing Returns and Economic Progress," Economic Journal, 38 (52), 52742. 